\title{
Liquid Chromatography Tandem Mass Spectrometry in Clinical Laboratories
}

\section{Mark M Kushnir ${ }^{1,2 *}$ and Alan L Rockwood ${ }^{1,2}$}

${ }^{1} A R U P \circledast$ Institute for Clinical and Experimental Pathology, Salt Lake City, USA

${ }^{2}$ Department of Pathology, University of Utah School of Medicine, Salt Lake City, USA

Liquid chromatography tandem mass spectrometry (LC-MS/ MS) has become one of the most powerful methodologies available in clinical diagnostic laboratories. Advantages of this technique over other chromatography and MS-based methods include simplified sample preparation, faster analysis time, greater specificity and throughput.

The ability of LC-MS/MS to be used for analysis of small and large molecules, thermo-labile and polar compounds has led to its wide adoption by clinical laboratories. During last decade a variety of LC-MS/MS methods have been introduced in fields of newborn screening, diagnostics of cancer, endocrine and metabolic diseases, nutrition, therapeutic drug monitoring, and microbiology [1-6]. The next challenging type of applications for clinical laboratories will be development of LC-MS/MS methods for quantitative measurement of proteins and peptides. LC-MS/MS is capable of providing high specificity/ high sensitivity measurements of proteins and peptides, especially when it is used in conjunction with affinity-based enrichment of targeted analytes [7-9]. Some methods for targeted protein and peptide analysis by LC-MS/MS have been already developed and it was demonstrated that these methods are capable of providing performance characteristics comparable to LC-MS/MS analysis of small bio-molecules. Expected advantages of such methods over immunoassays are superior specificity, lower cost, and more rapid method development. In the near future we likely will see growth of clinical protein/peptide LC-MS/MS applications comparable to one that has been seen for low molecular weight analytes during last decade.

LC-MS/MS technology was initially introduced in large clinical and reference laboratories, but it gets more and more adopted by smaller laboratories. Among many advantages of the technique are greater specificity, ability to assess specificity of analysis in every patient sample [10], and (in some cases) reduction in costs of testing. Main limitations to the wider adoption of the technique are the required large initial investment for purchase of the equipment, required expertise in method development, instrument operation, results interpretation, instrument maintenance and availability of expeditious support by the instrument manufacturers.

Numerous potential pitfalls exist and should be taken into consideration by the laboratories before implementing LC-MS/MS in their operation. It should be understood that mass spectrometrybased analytical methods are not automatically reference methodology, though it is possible to base reference methods on mass spectrometry, and as with other techniques utilized in clinical laboratories, mass spectrometry-based methods require development, optimization of all steps of the analysis, analytical and clinical validation of the methods, extensive training of personal, and consideration of potential preanalytical, analytical and post-analytical errors. Similarly to other analytical techniques, mass spectrometry-based methods can suffer from inadequate validation and standardization.

A number of reviews on mass spectrometry applications in clinical laboratories have been recently published [1-6,11,12]; these reviews contain useful methodological details, approaches for analysis of various biomarkers, and potential pitfalls associated with the use of LC-MS/MS. For LC-MS/MS methods one should carefully optimize all steps of sample preparation and instrumental analysis, including chromatographic separation, and to perform rigorous and systematic validation prior to introduction of the methods in clinical diagnostic practice. Comparison of several LC-MS/MS methods for quantification of testosterone $[13,14]$ showed the importance of adequate validation, availability and use of traceable reference standards and procedures.

It should be understood that poorly developed, inadequately validated analytical methods, lack of quality control, and poorly qualified technical personal will likely result in poorly harmonized methods and may cause harm both to patients and to the good standing of this very powerful technique. The above constraints should be understood and taken into consideration by clinical laboratories in order to realize full potential of LC-MS/MS in clinical diagnostics.

\section{References}

1. Shackleton C (2010) Clinical steroid mass spectrometry: a 45-year history culminating in HPLC-MS/MS becoming an essential tool for patient diagnosis J Steroid Biochem Mol Biol 121: 481-490.

2. Rauh M (2009) Steroid measurement with LC-MS/MS in pediatric endocrinology. Mol Cell Endocrinol 301: 272-281.

3. Kushnir MM, Rockwood AL, Roberts WL, Yue B, Bergquist J, et al. (2011) Liquid chromatography tandem mass spectrometry for analysis of steroids in clinical laboratories. Clin Biochem 44:77-88.

4. Strathmann FG, Hoofnagle AN (2011) Current and future applications of mass spectrometry to the clinical laboratory. Am J Clin Pathol 136: 609-616.

5. Kushnir MM, Rockwood AL, Bergquist J (2010) Liquid chromatography-tandem mass spectrometry applications in endocrinology. Mass Spectrom Rev 29: 480 502.

6. Grebe SK, Singh RJ (2011) LC-MS/MS in the Clinical Laboratory - Where to From Here? Clin Biochem Rev 32: 5-31.

7. Anderson L, Hunter CL (2006) Quantitative mass spectrometric multiple reaction monitoring assays for major plasma proteins. Mol Cell Proteomics 5 573-588.

8. Hoofnagle AN, Becker JO, Wener MH, Heinecke JW (2008) Quantification of thyroglobulin, a low-abundance serum protein, by immunoaffinity peptide enrichment and tandem mass spectrometry. Clin Chem 54: 1796-1804.

9. Bystrom CE, Salameh W, Reitz R, Clarke NJ (2010) Plasma renin activity by LC MS/MS: development of a prototypical clinical assay reveals a subpopulation

*Corresponding author: Mark M Kushnir, ARUP Institute for Clinical and Experimental Pathology, 500 Chipeta Way, Salt Lake City, UT 84108, USA, Fax: (801) 584-5207; E-Mail: kushnmm@aruplab.com

Received March 14, 2012; Accepted March 16, 2012; Published March 19, 2012

Citation: Kushnir MM, Rockwood AL (2012) Liquid Chromatography Tandem Mass Spectrometry in Clinical Laboratories. J Steroids Hormon Sci 3:e104 doi:10.4172/2157-7536.1000e104

Copyright: (c) 2012 Kushnir MM, et al. This is an open-access article distributed under the terms of the Creative Commons Attribution License, which permits unrestricted use, distribution, and reproduction in any medium, provided the original author and source are credited. 
Citation: Kushnir MM, Rockwood AL (2012) Liquid Chromatography Tandem Mass Spectrometry in Clinical Laboratories. J Steroids Hormon Sci 3:e104. doi:10.4172/2157-7536.1000e104

Page 2 of 2

of human plasma samples with substantial peptidase activity. Clin Chem 56: 1561-1569.

10. Kushnir MM, Rockwood AL, Nelson GJ, Yue B, Urry FM (2005) Assessing analytical specificity in quantitative analysis using tandem mass spectrometry. Clin Biochem 38: 319-327.

11. Vogeser M, Seger C (2010) Pitfalls associated with the use of liquid chromatography-tandem mass spectrometry in the clinical laboratory. Clin Chem 56: 1234-1244.
12. Soldin SJ, Soldin OP (2009) Steroid hormone analysis by tandem mass spectrometry. Clin Chem 55: 1061-1066.

13. Thienpont LM, Van Uytfanghe K, Blincko S, Ramsay CS, Xie H, et al. (2008) State-of-the-art of serum testosterone measurement by isotope dilution-liquid chromatography/tandem mass spectrometry. Clin Chem 54: 1290-1297.

14. Vesper HW, Bhasin S, Wang C, Tai SS, Dodge LA, et al. (2009) Inter-laboratory comparison study of serum total testosterone [corrected] measurements performed by mass spectrometry methods. Steroids 74: 498-503. 